\title{
Influence of Dante on the Iconographic Concept of the Last Judgement
}

\author{
Simeon Tomachinsky \\ Kursk Theological Seminary \\ Moscow Theological Academy \\ Moscow, Russia
}

\begin{abstract}
The article is investigating the history of appearance of purgatory in the iconographic model of the Last Judgment. Until the 18th century, representations of the afterlife exclusively included hell and heaven, and there was no purgatory. Starting from the second half of the 14th century, once the Divine Comedy of Dante was published, certain elements of purgatory started to appear, in particular, on frescoes of Nardo di Cione in the Florence Basilica of Santa Maria Novella. Some Last Judgement representations, dated back to the middle of the 15th century, began to suggest a certain structural accentuation of purgatory. The article analyses the influence of Dante's Divine Comedy on the afterlife iconography and offers conclusions about its special contribution into the development of iconographic concept of the Last Judgement.
\end{abstract}

Keywords-iconography; Last Judgement; purgatory; Divine Comedy; Dante; frescoes; Giotto; Nardo di Cione; Fra Angelico; Michelangelo; Rafael; Francis of Assisi

\section{INTRODUCTION}

The Russian iconic painting is not the only one to feature "the theology in living colour" since the Western church painting also translates images from theological ideas of the Roman Catholic world. Visual art is capable at times of expressing peoples' beliefs more vividly and deeply than some theological treatises.

More importantly, when it comes to spiritual reality, visual representations become a far greater importance for a Westerner than in the Orthodox Christian traditions with their ascetical prudence. In this regard, the review of purgatory's evolvement in the Western iconography seems very interesting.

\section{STAGES OF PURGATORY COMPOSITION}

As known, the Roman Catholic tenet about purgatory had been forming gradually, and it may be said that it "was coming into this world with pain". The most extensive investigation into the genesis of ideas about 'limbo' is offered by the renowned French cultural specialist Jacques Le Goff in his work "The Birth of Purgatory" [1].

Here are the milestones of purgatory's evolvement:
- The ideas pertaining to the 'purgatorial fire' (Origen and others) - the pre-Christian times and the first eleven centuries of Christianity;

- Invention of the word purgatorium, limbo, - the late 12 th century;

- The Union of Lyon between the Latin and Greek Churches; there was no such word as purgatory, but an idea of purgation - the Second Council of Lyon, 1274 ;

- An extended poetic religious concept of purgatory The Divine Comedy of Dante, 1321

- The Doctrine of Purgatory becomes the official teaching of the Roman Catholic Church - The Council of Ferrara-Florence, 1438-1439.

The present work attempts to retrace the influence of The Divine Comedy by Dante on the iconic vision of purgatory.

\section{THE LAST JUDGMENT IN THE TRECENTO REPRESENTATION}

Unfortunately, since it was impossible to find a comprehensive and complete research on the formation of the purgatory concept in afterlife iconography, the information was accumulated from different sources. According to art experts' repute, before the 14th century, purgatory was not in afterlife depiction. Frescoes with the Last Judgement depiction traditionally described an afterlife of the righteous and the sinners and heaven and hell, which once again bears witness to the point that Roman Catholic theology had not accepted the concept of purgatory down to the time of Dante.

We still find a two-part composition-hell and heaven in the frescoes of Dante's contemporary and renowned iconpainter Giotto in the Arena Chapel in Padua (completed in the early 14th century). According to V. D. Dazhina, the iconography of Giotto's "Last Judgment" "had close analogies with the byzantining style works of the 13th century and, in particular, with the frescoes in the Cathedral of Cefalu and in the dome of the Florentine baptistery" [2]

To the same 14th century belongs, for example, the fresco of the Last Judgement of unknown authorship in the Church of Santa Maria in Piano, an Italian town of Loreto 
Aprutino. The murals are portraying Christ enthroned and surrounded by saints. Below, souls of the dead are seen crossing a bridge, whereon they are met by Archangel Michael sitting in red robes, and Angels assist the righteous in getting to the other side. Some are toppling from the bridge down into the river, becoming prey of the devil "that prowls about like a roaring lion, seeking someone to devour" (1 Peter 5:8).

The similar story, with accentuation of Heaven and Hell, we find in other depictions of the Last Judgement up to the time of Dante, but the situation begins to change gradually after the appearance of his Devine Comedy.

In particular, the Federico Zeri Foundation from the University of Bologna has a rich stills library (http://www.fondazionezeri.unibo.it/it). When you search by the theme 'purgatorio' ('purgatory'), you get a few tens of images of different centuries. The earliest of them go back to the years of 1320-1325, in other words, just after Dante's death. This is a series of frescoes "Visione del Purgatorio" ("The Vision of Purgatory") by Giuliano da Rimini in the Basilica of Saint Nicholas in the Italian town of Tolentino. The murals are placed in the lower part of the southeastern wall. They depict figures enveloped in flames, including clergymen, with an angel floating above them.

Some subjects of the second half of the 14th century pertain to the intercession of Our Lady for souls in purgatory. We find frescoes painted by Biagio di Goro Ghezzi in the altar apse in the Church of St. Michael Archangel in Civitella Paganico (the series was finished by 1368). The fresco on the right wall, called "Our Lady advocates souls of Purgatory", portrays the Virgin Mary pulling with her hands a saved soul out of the hell pot enveloped in flames. The theme will become especially popular when portraying purgatory: the names of Carlo Sellitto, Cesare Sermei, Sebastiano Ricci, Marcello Fedeli, Federico Zuccari, Gian Paolo Cavagna and others can be cited here. More often than others in iconographic stories about Purgatory, we can find Saint Gregory the Great and Francis of Assisi.

According to Dante, the Mother of God, sitting in Heaven to the right of her Son, has a special gift of helping people. See as Bernard de Clairvaux addressing Her in his prayer of Canto XXXIII:

- La tua benignità non pur soccorre

- A chi domanda, ma molte fiate

- Liberamente al dimandar precorre.

(Par. 33:16-18) [3]

The Florentine Chapel Strozzi di Mantova contains one of the first images evidently influenced by The Devine Comedy. The assumption is that the murals in the Chapel Strozzi of the Basilica of Santa Maria Novella were painted by Nardo di Cione, possibly together with his brother Andrea di Cione, also called Orcagna, and, possibly, not without the participation of his son Giovanni. These frescoes, dated back to around 1360, are several decades after The Devine Comedy and were created under Dante's apparent influence.
This is all the more amazing since the Regional Council held in the same Basilica of Santa Maria Novella in 1335 forbade members of the Franciscan Order to read Dante.

The overall pattern of the triptych in the Chapel Strozzi is illustrative of the evangelical words of Christ, "Come ye, the blessed of my Father..." and "Depart from Me, accursed ones..." The central squinch arch is called "The Last Judgement" and is placed at the back of the Chapel around the stained glass painting of the Blessed Virgin Mary.

Right above it, in the central part of the composition, we see Christ, who administers judgement, sitting on clouds. Below there are Angels, the Mother of God, St. John the Baptist, the Apostles and, finally, at the bottom of the right side from Christ (or the left side when looking at the mural), there are the righteous, including Moses the Prophet, Holy Forefathers Noah, Isaac and others. The group of the blessed ones includes Dante in the praying position.

To the left of Christ, on the central wall and in the lunette symmetrically to the group of the righteous, we find the sinners, among whom we see also clergymen and laity, emperors and prominent figures. In particular, there are Cain, the Egyptian Pharaoh, the high-priest named Caiaphas and others.

The other two sections of the triptych depict in more detail men's afterlife destiny. The right section (leftward of the viewer) is called Heaven and the left one is called Hell. According to many researchers, the frescoes of Nardo di Cione present hell in Dante's interpretation, with nine circles and, for the first time, they portray purgatory as 'a superstructure' arranged above hell [4].

It is significant that the chapel with these murals is in the Basilica of Santa Maria Novella wherein the Pontifical household had stationed during the Council of Florence.

Another portrayal of "Purgatory" in the second half of the Trecento pertains directly to Canto X of Dante's "Purgatorio". This refers to the altar painting of Jacopino di Francesco de' Bavosi "Dormition of the Mother of the Virgin" with border scenes (1360-1380, Bologna, Picture Gallery). One of the border scenes is called "St. Gregory releases soul of the Emperor Trajan from Purgatory"; the other one, forming a pair with it, presents the Annunciation.

In Canto X of "Purgatorio", immediately after the entry into "the Second Kingdom" (which happened in Canto IX), Dante sees a marbled relief mural depicting three stories. The first two relate to the abovementioned representation: the Annunciation, when the Virgin Mary replies to the Angel "Ecce ancilla Dei" (Purg. 10:44) and to release of the soul of pagan Emperor Trajan through prayers of St. Gregory the Great - "the high glory of the Roman Prince, whose great beneficence moved Gregory to his great victory" (Purg. 10:74-75) [5].

\section{PURGATORY As PORTRAYED IN THE QUATTROCENTO}

At Dante's homeland in Florence, we find the famous murals of Fra Angelico and his school. According to an explicit statement given by V. D. Dazhina, "Fra Angelico 
produces the topography of Dante's Hell and Purgatory" [6]. His "Last Judgment" at the San-Marco Monastery in Florence, within the immediate vicinity of the Pontifical household during the Council of Ferrara-Florence, delivers Dante's idea through the language of painting. This concerns not just formal attributes - the afterlife itself "is perceived so spiritually that the sinners' suffering does no frighten, while the advent of Purgatory is infusing with hope" [7]. However, we do not see here any structural format of purgatory.

"The Last Judgement" of Fra Angelico dates back to 1422-1425, which means that it directly proceeds the Council of Ferrara-Florence. Remarkably, after the Council in 1442, Pope Eugene IV sent for Fra Angelico to decorate the Niccoline Chapel in Vatican. Moreover, the pontiff returns to Rome from Florence together with Fra Angelico had in hand [7].

Still, the first representation of purgatory as a specific place, structurally detached both from Heaven and Hell, appears only after the Council of Ferrara-Florence in 1453 as the corresponding article of the hallmark Lexicon of Theology and Church Terms relates this [8].

This was the great artwork "Coronation of the Virgin" (Villeneuve-lez-Avignon, The Museum Pierre de Luxembourg) made by Enguerrand Quarton in Avignon. The Blessed Virgin is crowned by the identical looking Father and the Son and the Holy Spirit in the form of a dove. On the right and left sides, they are surrounded by the dignitaries of the Church. The sinners further down are divided into two groups - those who are on the right from the viewer are tortured by demons and gradually move into Angels' arms (such is the portrayal of purgatory), while those on the right are burning in eternal hell fire of tortures. The representation has little in common with Dante's vision of purgatory, yet reflects resolutions of the Council of Florence, and, in particular, the idea of Filioque that erases the hypostatic differences between the Persons of the Holy Trinity.

It would be interesting to compare Quarton's painting, which offered the first structural appearance of purgatory, with another portrayal of the "Last Judgement" painted some years earlier in 1435 by the German painter Stefan Lochner. Lochner is considered to be one and the most important painter and representative of the so-called Cologne school: in particular, the famous altar triptych "The Adoration of the Magi" in the Cologne Cathedral, where the remains of the very three wise men are held, belongs to his brush.

Lochner's "Last Judgement" depicts the Judging Christ in glory, with kneeling Blessed Mother of God and St. John the Precursor at either side of him1. The procession of saints to the right of Christ is moving through the gates of heaven under Angels' protections; to the left, the sinners tormented by demons are falling down in hell where the devil is shown. Many images of this panel antedate the appearance of Bosch with his fantastic and grotesque imagery. In the central part of the panel, "in its mean place" we see souls invoking God's mercy. Compositionally and conceptually, they could well be

The picture can be seen on the Florence website:

http://scalarchives.it the souls of purgatory, but, on closer inspection, we see demons that drag them, tied down with ropes, towards the infernal abyss. The time of purgatory has not come yet.

Two decades had to pass, and everything would change. Approximately in the same time as Quarton's are dated, the frescoes in Terni (the region of Umbria) were at the Basilica of San Francesco in the Chapel that belonged to the Paradisi family. The murals are attributed to Bartolomeo di Tommaso da Foligno (died in 1454). They are describing the following scenes: the "Last Judgement" (in the lunette behind the altar, the central wall), "Heaven" (on the central wall behind the altar), "Hell" (on the right wall and in the lunette above the window), "Purgatory" (the lower part of the left wall) and "Christ's descent into Limbo" (the left wall, upper part, the lunette cut through by the window). Souls of purgatory are moving on and up to the mount in the direction shown by an Angel. The depiction corresponds to Dante's vision. Yet, in this case, purgatory's patterning again became possible only after the decisions passed by the Council of Ferrara-Florence.

The National Gallery of Art (Washington) contains a Florentine medal of the late 15th century (from the Samuel Cress' Collection). Its head side depicts Dante with a circumscription. Its backside shows the figure of The Divine Comedy's author outside the Mount Purgatory with three small figures atop.

\section{THE AFTER-WORLD AS PORTRAYED BY RENAISSANCE AUTHORS}

Dante's vision of the after-world had also been close to Luca Signorelli, who in 1499-1502 was finishing decoration of the Chapel of the Madonna di San Brizio, the murals of which initially began paint Fra Angelico back in 1447. According to V. D. Dazhina, while developing the program and selecting subjects, Signorelli also based on Dante's Divine Comedy, "the commenting on which had formed by that time a well-established humanistic tradition" [9]. Interestingly, the painter portrayed Dante among witnesses of the last battle with anti-Christ.

Signorelli had also placed Dante in the lower row of murals among those who forecast Apocalypses and who had apocalyptic vision: Ovid, Horatius, Virgilius, Homer, Lucian, Orpheus, and Empedocles" [9]. Here are also scenes from Dane's Purgatorio.

In the opinion of V. D. Dazhina, the fresco "Last Judgement" by Michelangelo in the Sistine Chapel had summarized the Renaissant perception of the end of the age theme [9]. We recognize here the apparent traces of Dante's influence as well.

Heinrich Pfeiffer gives a detailed look at the murals in his classic study "Discovered Sistine. Iconography of the masterpiece", which underwent many editions and was published in seven languages [10]. The author, Father Heinrich Pfeiffer, is a professor of Christian art history at the Pontifical Gregorian University in Rome. In particular, the scholar finds in Michelangelo's fresco of "Last Judgement" the theme of Dante's purgatory, and features of hell as interpreted in The Divine Comedy [10]. For instance, 
Michelangelo depicts Charon with an oar banishing from his boat souls of the sinners - the theme borrowed from Dante (Hell, 3:82 and on).

Michelangelo portrays young, beardless and naked Christ more like an ancient god. The technique of applying 'antique clothes' is repeatedly found in The Divine Comedy. For instance, while addressing Christ, Dante uses the name Giove, Jupiter:

- Es se licito m'e, o sommo Giove,

- Che fosti in terra per noi crucifisso,

- Son le giusti occhi tuoi rivolti altrove?

(Purg. 6:118-120) [11]

The same Sistine Chapel contains a separate portrayal of Dante painted by Raphael. In his Stanze (Raphael Rooms), Dante is shown among the righteous men that surround altar: Francis of Assisi, Angelic Doctor, Bonaventure and others. The fresco, created in 1508-1511 in Palazzi Pontifici in the Vatican, is called "The Disputation of the Sacrament".

In the same place, on the opposite wall there us the fresco "The School of Athens" that depicts Ancient philosophers Plato, Aristotle and others. Art experts consider the organic combining by Raphael of Christian and antique images, grafting the Christianity into "antique tree" to be one of the major artistic accomplishments of the master. Such task had been previously successfully accomplished in The Divine Comedy, and Dante's appearance in Raphael's Stanze was not an accidence.

An equally significant influence of Dante's concept can be seen on the Last Judgment (Il Giudizio Universale) under the dome of the Cathedral of Santa Maria del Fiore in Florence painted by Giorgio Vasari and Federico Zuccari in the period from 1572 through to 1579 . Particularly, an almost completed figure of Lucifer, painted by Vasari, corresponds the description offered by The Divine Comedy [13].

The Church of the Most Holy Name of Jesus (Chiesa del Santissimo Nome di Gesù), its Chapel of Angels in Rome, contains the fresco of Federico Zuccari "Angels liberate souls from Purgatory" dated back to 1599-1600. It depicts Angels presenting souls, purified in Purgatory, to Christ and the Mother of God on high. The fresco perfectly fits in the suggested by Dante's interpretation of the 'middle place' wherefrom souls proceed gradually to Heaven.

Following the Council of Ferrara-Florence, the number of purgatory representations started to grow, and their brief review can take many pages. It is obvious that the concept of purgatory had been fully accepted by the Western iconographic tradition.

In 1465, Domenico di Michelino created quite a symbolic picture, which is called "The Comedy Illuminating Florence". It presents Dante standing in the center with a copy of The Divine Comedy in his hand. To the right, there is the mount of Purgatory with sinners climbing on; to the left, there is the
Cathedral of Santa Maria del Fiore, where the Council of Ferrara-Florence was held 26 years before.

The painter's ideas may be interpreted as if the Council had adopted the doctrine of purgatory under the influence of Dante's work that gave people hope.

There is a series of illustrations to The Divine Comedy drawn by Sandro Botticelli. The original manuscript is kept in the Vatican Library, but the drawings were repeatedly reproduced in subsequent reprints.

One of the most explicit illustrations of Dante's influence on perception of the after-world can be found in the Assisi Cathedral, the bosom of the Franciscan Order, which was mainly decorated with frescoes painted by Giotto di Bondone. Other outstanding painters like Cimabue, Pietro Lorenzetti, Simone Martini and others also took part in the decoration.

In the Lower Church, under the altar of which is placed the tomb of St. Francis of Assisi, Giotto symbolically painted St. Francis' natural virtues that describe the three monastic vows: poverty, chastity and obedience. Some art experts attribute the frescoes in the pendentives of the basilica to Giotto's pupil, not to the master, as "the monastic direction" in allegories was not common for Giotto. Still, this does not signify in this particular case.

On the right pendentive from the altarpiece, there is the fresco dedicated to chastity that portrays Dante in Franciscan habit receiving in blessed dwelling those who managed to acquire this virtue. On the opposite side, angels and saints are wording off daemons. In in the central part in a window of the white tower, we see the Virgin to whom two angels bring a wreath and a flower.

Such a prominent role that is assigned to the author of The Divine Comedy arises from the fact that Dante belong to the Franciscan Order. As a young man, he even went through novitiate in the brotherhood. The Franciscans has a kind of three branches: friars as such, women and laypeople. Dante belonged to the third category, and there is evidence that before his death he ordered to dress him into a brown cowl, which was allowed to Franciscan tertiaries [15].

The artistic concept of the Cathedral paintings belongs to the Franciscans themselves, the Order treated Dante with great reverence2. Dante's work was highly appraised by his contemporary Giotto.

The author of The Divine Comedy had found his final abode in a Franciscan friary in Ravenna, where the Basilica with his tomb is. At one time, when Florentines tried to get back home the exile's remains, the Franciscans sent them just an empty coffin.

The Florentine Basilica di Santa Croce, poetized by Dante in front of which stands his monument today, also belonged to the Franciscan order. Moreover, there are many such links.

\footnotetext{
2 The information is provided by the Franciscans from the Sacro Convento friary in Assisi during the author's visit there on May 12, 2017.
} 
"Nacque al mondo un Sole" - "A sun was born into the world (Paradiso, 11, 50), - Dante wrote this about Saint Francisco of Assisi, to whom he dedicated Canto XI of "Paradiso, in which the poet narrates about the inception of the Franciscan order:

- Ma regalmente sua dura intenzione

- As Innocenzio apere, e da lui ebbe

- Primo sigillo a sua religion.

(Par., 11:91-93) [16].

Special attention should be given to the fact that Francisco of Assisi was among the first to use for his literature and theological purposes Italian common language, volgare. In particular, his famous "Canticle of Creation" ("Il cantico delle creature" or "Il cantico di Frate Sole") and "The Simple Prayer" (Preghiera semplice) were written in Italian. Even here, the closeness of views of the Franciscan Order's founder and Dante's ideas can be traced.

Small wonder three centuries later, when the altarpiece of the Cathedral's Lower Church was newly decorated, Dante's influence was most pronounced. The apse fresco, painted in absolutely different style than Giotto's school, depicts the Last Judgement. Cesare Sermei created the masterpiece in 1623.

This fresco describes not only heaven and hell, but also a structurally outlined purgatory, out of which the Franciscans help sinners get out with the help of their woven belts. Many details speak of the assimilation of Dante's concept of the after-world. In particular, Muhammad is being depicted in hell, just as The Divine Comedy narrates about this (Eighth Circle of Inferno).

\section{CONCLUSION}

Before the 14th century, there had been no purgatory in representations of the Last Judgement. The elements of afterlife, borrowed from Dante, began to appear starting from the time when The Divine Comedy was wrote, namely, after 1321. In this time, purgatory is not yet structurally defined but is present either in the form of detached elements or as a superstructure existing above fell. Such representations frequently accentuate protection of the Blesses Mother of God and individual saints.

Almost all outstanding painters of the 15th and 16th centuries, depicting the Last Judgment, such as Fra Angelico, Signorelli, Michelangelo, Raphael and Vasari, were largely following Dante's conception of the after-world and portrayed Dante among the righteous and masters. This clearly shows how great the influence of The Divine Comedy on appreciation of the life after death and at what extent Dante's vision of purgatory became organic to the Western mind was. These facts are indicative of inclusion of Dante in the pantheon of makers of the after-life views.

\section{REFERENCES}

[1] J. Le Goffe, The Birth of Purgatory / Translation from French by B Babinsky and T. Krayevaya, Yekaterinburg: U-Factoria; M.: Astrel', 2011, pp. 5-542.

[2] V. D. Dazhina, Message of «the end of the age" in the Italian Renaissance art // Italian collection, Issue 3, M.: Monuments of Historic Thought, 2003, p. 215.

[3] Dante Aligheri, Divina Commedia / Introduzione di Italo Borzi; Commento a cura di Giovanni Fallani e Silvio Zennaro, Roma: Newton, 2012, p. 642.

[4] A. Maikapar, Last Judgement // http://files.schoolcollection.edu.ru/dlrstore/f5390dd3-58c8-4ae1-a74d4c44b3fefa18/Sujeti/VI.Po_Voznesenii/80.Strachnii_Sud/Strashnii_S ud.htm(accessed date - 28.12.2015)

[5] Dante Aligheri, Divina Commedia, p. 291.

[6] V. D. Dazhina, Message of «the end of the age" in the Italian Renaissance art, p. 223.

[7] John Norwich, A history of the Papacy/ Translated from English by A. Korolenkov and E. Semenova, M.: AST, 2014, p. 311.

[8] Lexikon für theologie und Kirche. Verlag Herder Freiburg, 1986, p. 55 .

[9] V. D. Dazhina, The message of «the end of the age" in the Italian Renaissance art, c. 219.

[10] H. Pfeiffer, La Sistina svelata. Iconografia di un capolavoro, Jaca Book, 2007.

[11] Dante Aligheri, Divina Commedia, p. 269

[12] P.P. Muratov, Images of Italy: Complete edition: Vol. I-III, Historical guidebook, M.: Izdatelstvo V. Shevchuk Publishing House, 2016, p. 294.

[13] G. Giacomelli. Il Guidizio universale di Vasari e Zuccari fra chiesa, corte e teatro musicale. // Recercare. Vol. 20, n 1/2 (2008), pp. 95115. Fondazione Italiana per la Musica Antica, p. 109.

[14] P. P. Muratov, Images of Italy, p. 442

[15] G. Chistyakov, Conversations about Dante, M.: Book Center Rudominon, 2016, p. 194.

[16] Dante Aligheri. Divina Commedia, p. 501. 